\title{
Elaboration of porous gehlenite and anorthite based ceramics using low price raw materials
}

\section{(Elaboração de cerâmicas a base de guelenita e anortita usando matérias-primas de baixo custo)}

\author{
F. Zenikheri, A. Harabi, B. Boudaira, F. Bouzerara, A. Guechi, S.-E. Barama, L. Foughali, N. Karboua \\ Ceramics Lab., Physics Department, Faculty of Exact Science, Mentouri University of Constantine, \\ Constantine, Algeria \\ ph_zenikheri@yahoo.fr,harabi52@gmail.com,boudaira.boukhemis@gmail.com,bouzerara_ferhat@yahoo.fr, \\ guechia@yahoo.fr,sebarama@usa.com,foughali_lazhar@yahoo.fr,kanour17@yahoo.fr
}

\begin{abstract}
Porous ceramics of good quality cost a lot in the world market, which has limited their use in developing countries. This is why this work was mainly devoted to prepare low-cost and good quality ceramics, using kaolin (DD2 type) and calcite $\left(\mathrm{CaCO}_{3}\right)$ available in abundance in Algeria. Based on previous results, $28 \mathrm{wt} \% \mathrm{CaCO}_{3}$ ceramic was selected. The presence of $\mathrm{CaCO}_{3}$ favors to achieve porous samples characterized by a high percentage of porosity due to the $\mathrm{CO}_{2}$ release and $\mathrm{CaO}$ formation during its calcination at about $700{ }^{\circ} \mathrm{C}$. The choice of these raw materials is based on their natural abundance (low price). It has been found that the samples had interesting characteristics: average pore size between 2.87 and $6.50 \mu \mathrm{m}$ and porosity between 53 and $57 \%$. It has also been found that the manufactured membrane supports are mainly constituted of gehlenite and anorthite phases. Moreover, the pore size distribution was mono-modal type. The surface and cross-section morphologies observed through a scanning electron microscope were also homogeneous and do not present any possible macro-defects (cracks, etc.).
\end{abstract}

Keywords: kaolin, calcite, membrane, support.

\section{Resumo}

Cerâmicas porosas de boa qualidade apresentam elevados preços no mercado mundial, o que têm limitado seus usos nos países em desenvolvimento. Este é o motivo deste trabalho se dedicar a preparar cerâmicas de baixo custo e boa qualidade usando caulim (tipo DD2) e calcita ( $\mathrm{CaCO}_{3}$ ) disponíveis em abundância na Argélia. Com base em resultados anteriores, foi selecionada a cerâmica com $28 \%$ em massa de $\mathrm{CaCO}_{3}$. A presença de $\mathrm{CaCO}_{3}$ favorece obter amostras porosas caracterizadas por uma alta porcentagem de porosidade, devido à liberação de $\mathrm{CO}_{2}$ e formação de $\mathrm{CaO}$ durante sua calcinação em cerca de $700^{\circ} \mathrm{C}$. A escolha destas matérias-primas é baseada nas suas abundâncias naturais (baixo preço). Foi observado que as amostras apresentaram características interessantes: tamanho médio de poro entre 2,87 e 6,50 $\mu \mathrm{m}$ e porosidade entre 53 e $57 \%$. Também foi observado que suportes de membrana manufaturadas são constituídas principalmente de fases guelenita e anortita. Além disso, a distribuição de tamanho de poro foi monomodal. As morfologias da superficie e seção transversal observadas em microscópio eletrônico de varredura também foram homogêneas e não apresentaram nenhum defeito macroscópico (trincas, etc.).

Palavras-chave: caulim, calcita, membrana, suporte.

\section{INTRODUCTION}

In recent years, a great deal of research has been devoted to the development of new types of inorganic membranes, mainly due to the lower price of the raw material available. A lot of countries in the world have abundantly available raw materials, such as calcite $\left(\mathrm{CaCO}_{3}\right)$, dolomite $\left(\mathrm{CaCO}_{3} \cdot \mathrm{MgCO}_{3}\right)$, bones (natural derived hydroxyapatite, $\left.\mathrm{HA}, \mathrm{Ca}_{10}\left(\mathrm{PO}_{4}\right)_{6}(\mathrm{OH})_{2}\right)$, kaolin, feldspar and quartz. Many works have already been published for valorizing these native raw materials, for the production of advanced ceramics [1-3], ceramic membranes [4-19] and bioceramics [20-29]. Most of these publications are closely related to this work and clearly highlight their possible multifunctional applications. Ceramic filters are generally constituted of a thick support $(2000 \mu \mathrm{m})$ and mono or multiple thin membranes (from 10 to $40 \mu \mathrm{m}$ for each one). Therefore, replacing the more expensive starting materials, mentioned above, by cheaper raw materials used in supports (which constitute about $99 \%$ of the filter mass) is significantly important. So, what do low cost raw materials mean? The alumina price is at least about 100 times greater than that of kaolin. Another important advantage is the substantial gain in energy obtained by decreasing the sintering temperature from about $1600{ }^{\circ} \mathrm{C}$ to about $1250{ }^{\circ} \mathrm{C}$, when alumina supports are replaced by the proposed supports. Besides this, about $50 \%$ of the prepared supports are porous, which may also be considered as a gain in mass. The relatively lower theoretical density of the prepared supports $\left(2.8 \mathrm{~g} / \mathrm{cm}^{3}\right)$ when 
compared to that of alumina $\left(3.98 \mathrm{~g} / \mathrm{cm}^{3}\right)$ is also another interesting advantage. Some simple calculations may show the advantages mentioned above. One can claim that there is no need to do calculations if these low cost manufactured supports do not obey to the main internationally required support characteristics. Consequently, previous work [9] was integrally devoted to go through each of these characteristics. So, one can scientifically conclude that alumina may be replaced by these two rocks (kaolin and calcite). Fortunately, a three-point flexural strength of $87 \pm$ $2 \mathrm{MPa}$ was obtained for $100 \mathrm{wt} \% \mathrm{Al}_{2} \mathrm{O}_{3}$ samples sintered at $1620^{\circ} \mathrm{C}$ for $2 \mathrm{~h} \mathrm{[30],} \mathrm{whilst} \mathrm{nearly} \mathrm{the} \mathrm{same} \mathrm{flexural} \mathrm{strength}$ value $(87 \pm 6 \mathrm{MPa})$ was also measured for compacts sintered only at $1250^{\circ} \mathrm{C}$ for $1 \mathrm{~h}$, using the proposed process [9]. Even though, kaolin clay ( $5 \mathrm{wt} \%$ ) was added into $\mathrm{Al}_{2} \mathrm{O}_{3}$ as a paste plasticizer during forming, as well as a sintering aid, the used sintering temperature was still considerably higher.

Moreover, this support [9] and/or other supports [416] were applied for elaboration of low cost ceramics microfiltration membranes applied to the sterilization of plant tissue culture media [17]. A membrane support provides mechanical strength to a membrane top layer to withstand the stress induced by the pressure difference applied over the entire membrane and must simultaneously have a low resistance to the filtrate flow. Membrane processes are more and more used in industrial processes such as water treatment and surface industries with a wide variety of modules designs [31]. The development of membrane processes to treat wastewater is generally limited because the price of the membranes is too high, which is particularly true for the inorganic membranes [32]. A significant effort has been taken in the last years in membrane technology field in order to find out new porous ceramics materials at low price [33] because the marketed supports are generally manufactured from compounds such as alumina $\left(\mathrm{Al}_{2} \mathrm{O}_{3}\right)$, cordierite $\left(2 \mathrm{MgO} .2 \mathrm{Al}_{2} \mathrm{O}_{3} .5 \mathrm{SiO}_{2}\right)$, and mullite $\left(3 \mathrm{Al}_{2} \mathrm{O}_{3} .2 \mathrm{SiO}_{2}\right)$ [34-38]. An alternative process is proposed in this work in order to obtain mullite based ceramics without the undesirable cristobalite phase. This process consists of adding an amount of calcite $\left(\mathrm{CaCO}_{3}\right)$ into kaolin or metakaolin (calcined kaolin) to obtain, at relatively lower sintering temperatures, anorthite $\left(\mathrm{CaO} \cdot \mathrm{Al}_{2} \mathrm{O}_{3} \cdot 2 \mathrm{SiO}_{2}\right)$ based ceramics. Taking into account the attractive properties of anorthite phase, the preparation of cristobalite free ceramics from kaolin-calcite mixtures is studied.

\section{MATERIALS AND METHODS}

Sample preparation: the starting raw materials were domestic kaolin (DD2) and calcite $\left(\mathrm{CaCO}_{3}\right)$ derived from Guelma and Constantine regions (Algeria), respectively. The kaolin (DD2) was properly crushed, then calcined at $600{ }^{\circ} \mathrm{C}$ for $1 \mathrm{~h}$ to be later on sieved at $200 \mu \mathrm{m}$. After that, a quantity of $28 \mathrm{wt} \%$ of calcium carbonate powder was added. In order to improve the properties and facilitate the forming, this mixture should be continuously mixed up with water (Fig. 1). Subsequently, the specimens in the form of discs of

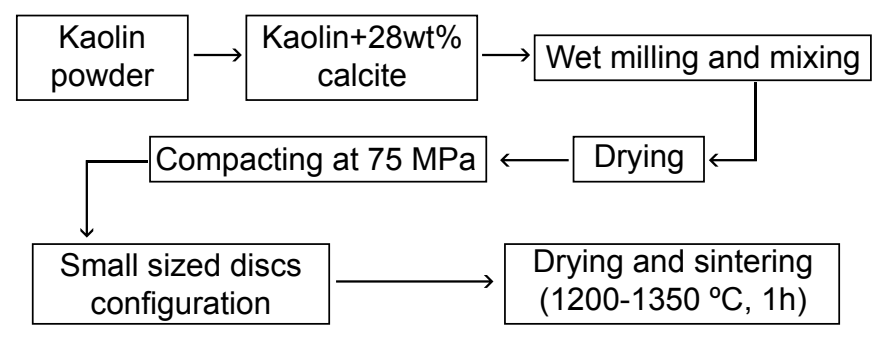

Figure 1: Schematic diagram showing the process used in this work for membrane supports preparation.

[Figura 1: Diagrama esquemático mostrando o processo usado neste trabalho para preparação de suportes de membrana.]

about $13 \mathrm{~mm}$ diameter and 2 to $5 \mathrm{~mm}$ thickness were obtained by compacting with a laboratory uniaxial press at $75 \mathrm{MPa}$. It should be noticed that these forms and dimensions of samples were used for all the following characterization techniques. The samples were subsequently sintered at a temperature ranged between 1200 and $1350{ }^{\circ} \mathrm{C}$ for $2 \mathrm{~h}$ in an electrically operated laboratory furnace using on/off control system. A constant heating rate of about $5{ }^{\circ} \mathrm{C} \cdot \mathrm{min}^{-1}$ was maintained during firing.

Characterization techniques: the particle size distribution of the starting materials were measured in a water suspension after ultrasonic dispersion using a laser granulometer (Coulter LS230, Malven Instruments, France). The total porosity and pore size distribution were measured by mercury porosimetry (Autopore 9500, Micromeritics). This technique is based on the penetration of mercury into a membrane's pore under pressure. The intrusion volume is recorded as a function of the applied pressure and then the pore size is determined. Phase compositions of prepared samples were identified by X-ray diffraction (XRD) (D8 Advance, Bruker, Germany) with a $\mathrm{Cu}-\mathrm{K} \alpha$ radiation $(\lambda=0.154 \mathrm{~nm})$ and a Ni filter, working voltage of $40 \mathrm{kV}$, and working current of $30 \mathrm{~mA}$. The microstructure of sample surfaces was observed using a scanning electron microscope (SEM, JSM-6301 F, Hitachi, Japan) working at $7 \mathrm{kV}$ as an accelerating voltage. Before SEM observation, all samples were gold coated. Structural evolutions of kaolin and calcite powders were evaluated by thermogravimetric analysis (TGA) and differential scanning calorimetry (DSC), using a Setaram TG-DTA 92 apparatus. These two analyses have been carried out under air. The heating rate of the compacts from room temperature to $1200^{\circ} \mathrm{C}$ was $10^{\circ} \mathrm{C} / \mathrm{min}$, while the cooling of compacts was carried out in the furnace.

\section{RESULTS AND DISCUSSION}

\section{Characterization of starting materials}

Fig. 2 illustrates the particle size distributions of the two raw materials (kaolin and calcite). Their average particle sizes were in the order of 2.2 and $4.8 \mu \mathrm{m}$, respectively. The SEM image shows that the natural kaolin (DD2) powder crystallizes nicely in the form of naturally hollow nano-rods halloysite crystals and had almost the same mean particle 

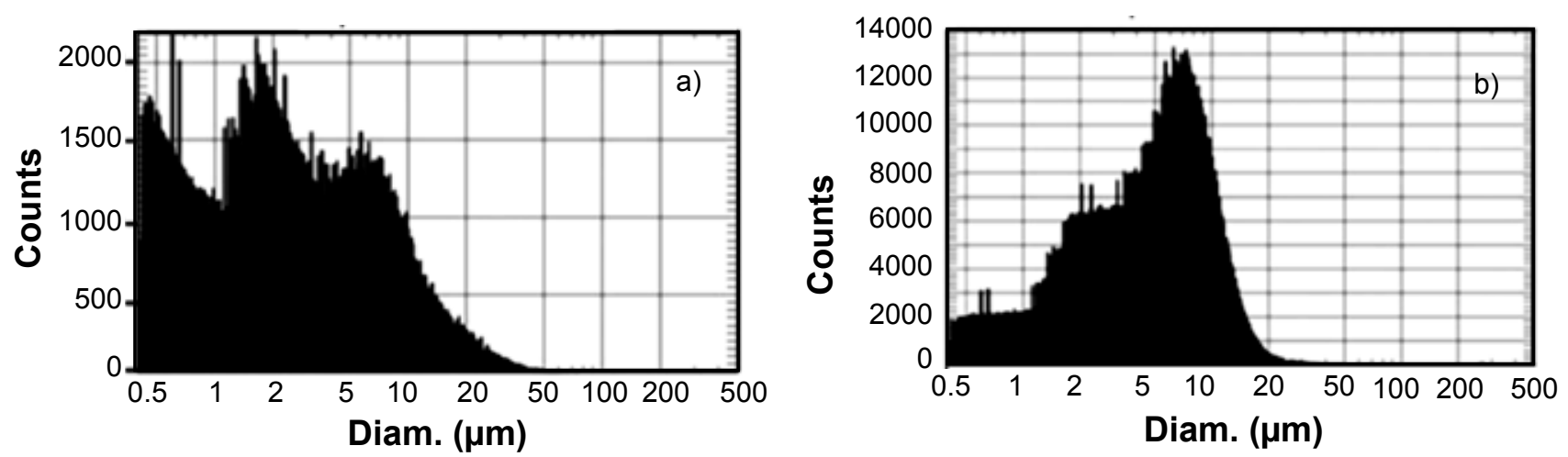

Figure 2: Particle size distributions of powders: (a) kaolin (DD2) and (b) calcium carbonate $\left(\mathrm{CaCO}_{3}\right)$.

[Figura 2: Distribuições granulométricas dos pós: (a) caulim (DD2) e (b) carbonato de cálcio (CaCO$)_{3}$.]
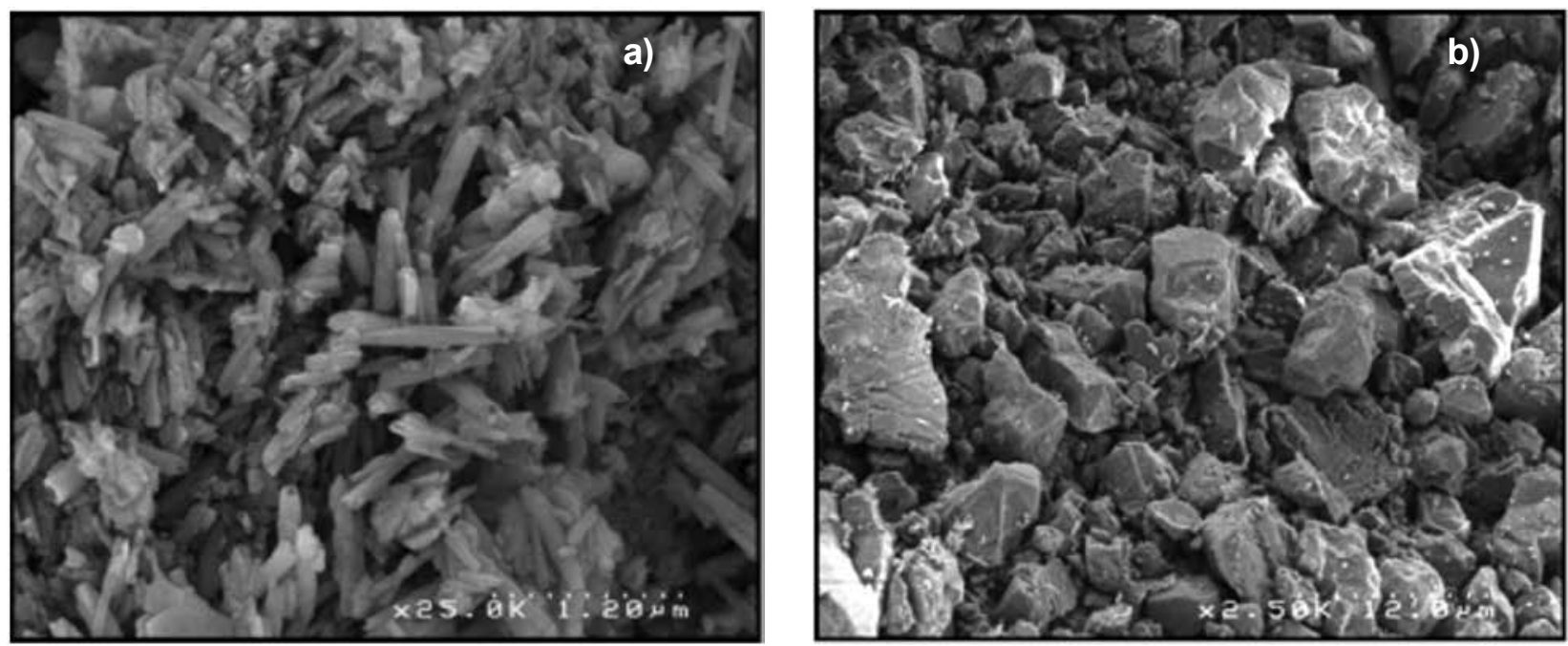

Figure 3: SEM micrographs of: (a) natural kaolin (DD2) and (b) calcium carbonate.

[Figura 3: Micrografias obtidas por microscopia eletrônica de varredura do: (a) caulim (DD2) e (b) carbonato de cálcio.]
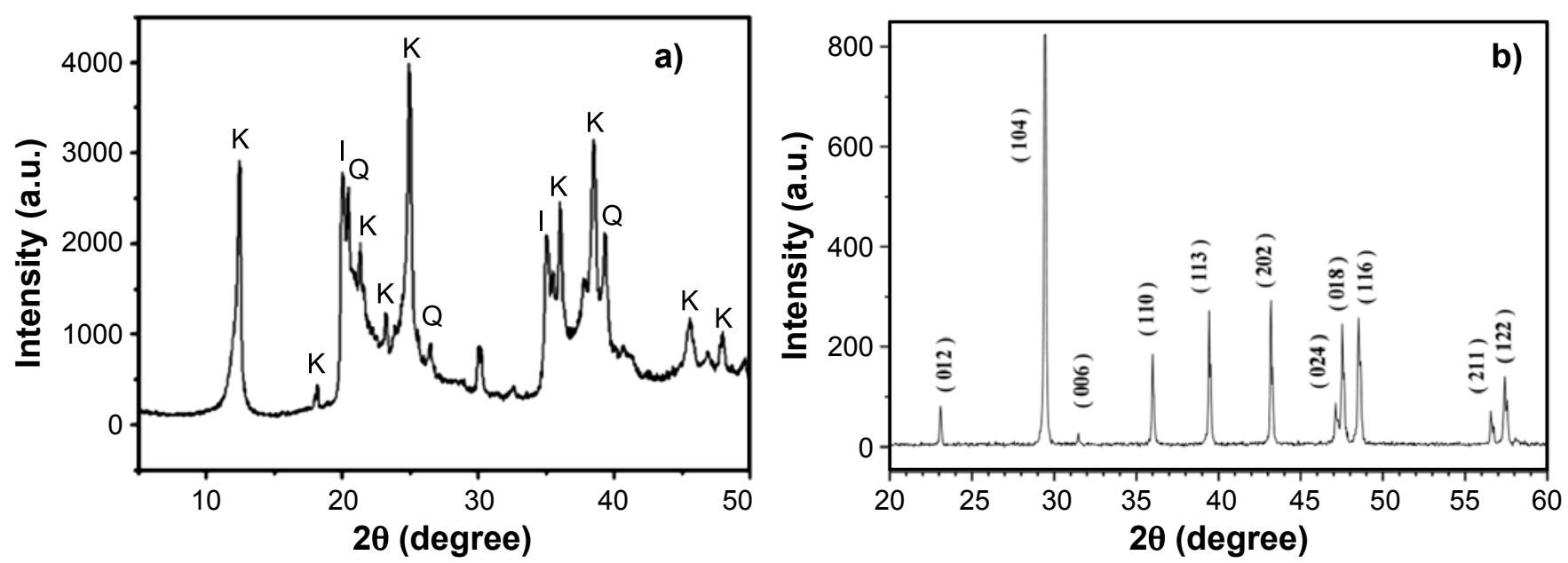

Figure 4: X-ray diffraction patterns of: (a) natural kaolin DD2 (C: carbonate; I: illite; K: kaolinite; Q: quartz); and (b) calcium carbonate powder. [Figura 4: Difratogramas de raios X do: (a) caulim natural DD2 (C: carbonato; I: ilita; K: caulinita; Q: quartzo); e (b) pó de carbonato de cálcio.]

size and a homogeneous distribution (Fig. 3a). On the other hand, the calcite does not have a particular form, but its distribution remains homogeneous (Fig. 3b).

The chemical composition of kaolin (DD2) given in weight percentages ( $\mathrm{wt} \%$ ) of oxides is given in Table I. The obtained results reveal that this kaolin is mainly composed of silica $\left(\mathrm{SiO}_{2}\right)$ and alumina $\left(\mathrm{Al}_{2} \mathrm{O}_{3}\right)[12]$. The quantitative analysis of calcium carbonate showed that the purity of 
Table I - Chemical composition of kaolin DD2 (wt\%) by $\mathrm{XRF}$ analysis.

[Tabela I - Composição química do caulim DD2 $1 \% \mathrm{em}$ massa) por análise FRX.]

\begin{tabular}{ccccccccc}
\hline $\mathrm{SiO}_{2}$ & $\mathrm{Al}_{2} \mathrm{O}_{3}$ & $\mathrm{TiO}_{2}$ & $\mathrm{Fe}_{2} \mathrm{O}_{3}$ & $\mathrm{~K}_{2} \mathrm{O}$ & $\mathrm{Na}_{2} \mathrm{O}$ & $\mathrm{CaO}$ & $\mathrm{MgO}$ & I.L. \\
\hline 45.00 & 33.43 & 0.22 & 0.23 & 0.95 & 1.12 & 0.32 & 0.03 & 18.73 \\
\hline I.L. - ignition loss. & & & & & & & &
\end{tabular}

this raw material is about $99.6 \%$ [16]. The XRD pattern of the kaolin (Fig. 4a) shows that kaolinite (K), illite (I), and quartz (Q) are the main minerals present in the clay. Fig. 4b shows XRD spectrum of calcium carbonate powder, where only $\mathrm{CaCO}_{3}$ is present. This spectrum shows also that the calcium carbonates powder is well crystallized [9].

\section{Thermal analysis}

The thermal analysis recorded during heating compacts (Fig. 5) permits the following remarks: the DSC curve of natural kaolin and calcium carbonate mixture (Fig. 5) show characteristic endothermic peaks at 51.18, 488.98 and $727.15^{\circ} \mathrm{C}$. The first one is attributed to the humidity (water added into the starting mixtures), whereas the second stage is related to the departure of water (by vaporization) existing in the kaolin chemical composition itself [13]. However, the third peak is due to the thermal decomposition of calcite to form calcium oxide $(\mathrm{CaO})$ and $\mathrm{CO}_{2}[13]$ whereas the later peak may be attributed to mullite nucleation [13]. These observations are also confirmed by TGA analysis (Fig. 5) which permits the following remarks: a total weight loss of about $10 \%$ of kaolin (peaked at 51.18 and $488.98{ }^{\circ} \mathrm{C}$ ) and $11.5 \%$ of calcite (peaked at $727.15^{\circ} \mathrm{C}$ ) were determined.

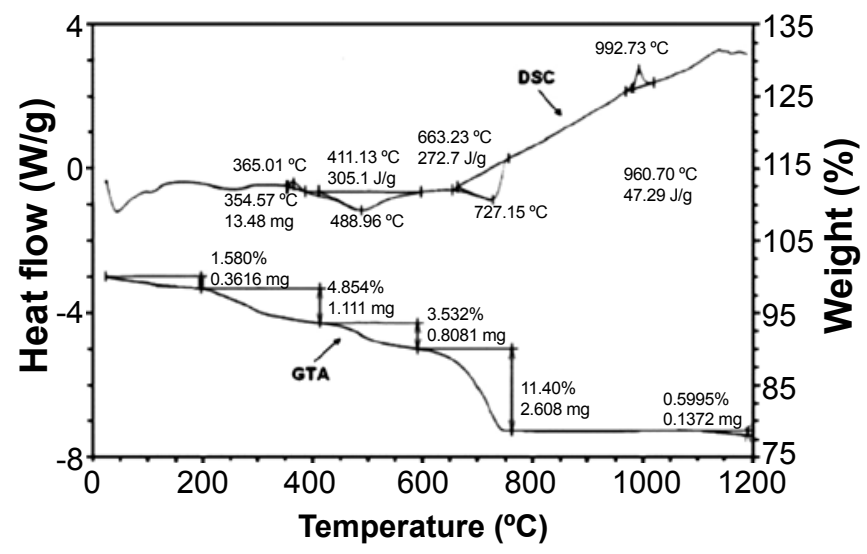

Figure 5: DSC and TGA curves of natural kaolin and calcium carbonate mixture.

[Figura 5: Curvas de DSC e TGA da mistura de caulim natural e carbonato de cálcio.]

\section{Pore characterization}

For the development of high-quality supports, the following properties are of major importance: pore size distribution, total porosity ratio, mechanical properties and chemical stability. The pore coalescence becomes a predominant factor when $28 \mathrm{wt} \%$ of calcite was added. The porosity values are all over $50 \%$ (Table II). These high values were probably due to the liberation of $\mathrm{CO}_{2}$ from $\mathrm{CaCO}_{3}$ during sintering. According to the obtained results, it has been found that the pore size distribution was almost homogeneous (mono-modal type). In order to find out the lowest or convenient sintering temperature, samples were subsequently sintered at different temperatures (1200 to $1350^{\circ} \mathrm{C}$ ). One can notice from Table II that a uniform pore size distribution, with total porosities ranging between 53 and $57.8 \%$, was successfully achieved. As shown in Fig. 6 , porosity and average pore size (APS) behave similarly as a function of sintering temperature. For example, the porosity decreased from $57 \%$ to about $53 \%$ when sintering temperature increased from 1200 to $1350{ }^{\circ} \mathrm{C}$, whilst APS increased from 2.87 to $6.50 \mu \mathrm{m}$ at the same sintering temperature interval. This behaviour may be due to a better sintering. However, the pore characterization may be divided into three main categories [9]. These consist of the total porosity, APS and the modal of pore size distribution. The pore size distribution modal may also be classified into three distinct modals: single or Gaussian distribution, bi-modal and multi-modal pore size. The pore size indicates that this kind of membranes can be used in the MF range [9]. Fig. 7 illustrates the modal distributions of pore size, for samples sintered at different temperatures for $1 \mathrm{~h}$, using mercury porosimetry. It is clear that the pore size distribution modal is temperature dependent. It is almost mono-modal distribution (uniform distribution) in all compacts sintered at 1200 and $1250{ }^{\circ} \mathrm{C}$. On the basis of the results mentioned above, it can be said that the increase in sintering temperature causes the coalescence of pores which, in turn, leads to a larger APS [9]. At higher temperatures, samples APS shift towards larger values. All this may be caused by many factors such as the rise in particles contact areas, the gap vanishing as a result of the organic combustion and water evaporation during the early holding sintering times. Afterwards, the samples reach their highest porosity value. Generally, there is an increase in APS and a decrease in total porosity in samples, when the sintering temperature is increased. This increase in APS is also confirmed by typical micrographs, as illustrated in Fig. 8 [9].

Table II - Porosity characteristics of samples prepared from kaolin and calcite mixture.

[Tabela II - Características de porosidade de amostras preparadas a partir da mistura de caulim e calcita.]

\begin{tabular}{ccccc}
\hline $\begin{array}{c}\text { Sintering } \\
\text { temperature } \\
\left({ }^{\circ} \mathrm{C}\right)\end{array}$ & $\begin{array}{c}\mathrm{CaCO}_{3} \\
(\mathrm{wt} \%)\end{array}$ & $\begin{array}{c}\text { Porosity } \\
(\%)\end{array}$ & $\begin{array}{c}\text { APS } \\
(\mu \mathrm{m})\end{array}$ & $\begin{array}{c}\text { Distribution } \\
\text { modal }\end{array}$ \\
\hline 1200 & 28 & 57.2 & 2.9 & SMPSD \\
1250 & 28 & 57.8 & 3.2 & SMPSD \\
1300 & 28 & 56.2 & 3.4 & SMPSD \\
1350 & 28 & 53.1 & 6.5 & SMPSD \\
\hline
\end{tabular}




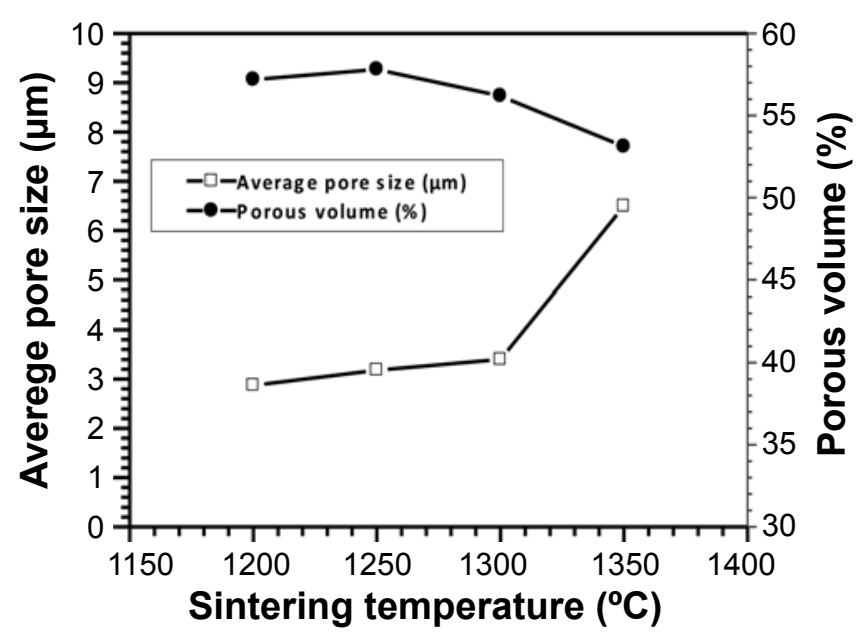

Figure 6: Porosity and APS for kaolin $+28 \mathrm{wt} \%$ calcite mixture sintered at different temperatures for $1 \mathrm{~h}$.

[Figura 6: Porosidade e tamanho médio de poro para mistura caulim $+28 \%$ de calcita sinterizada em diferentes temperaturas por 1 h.]
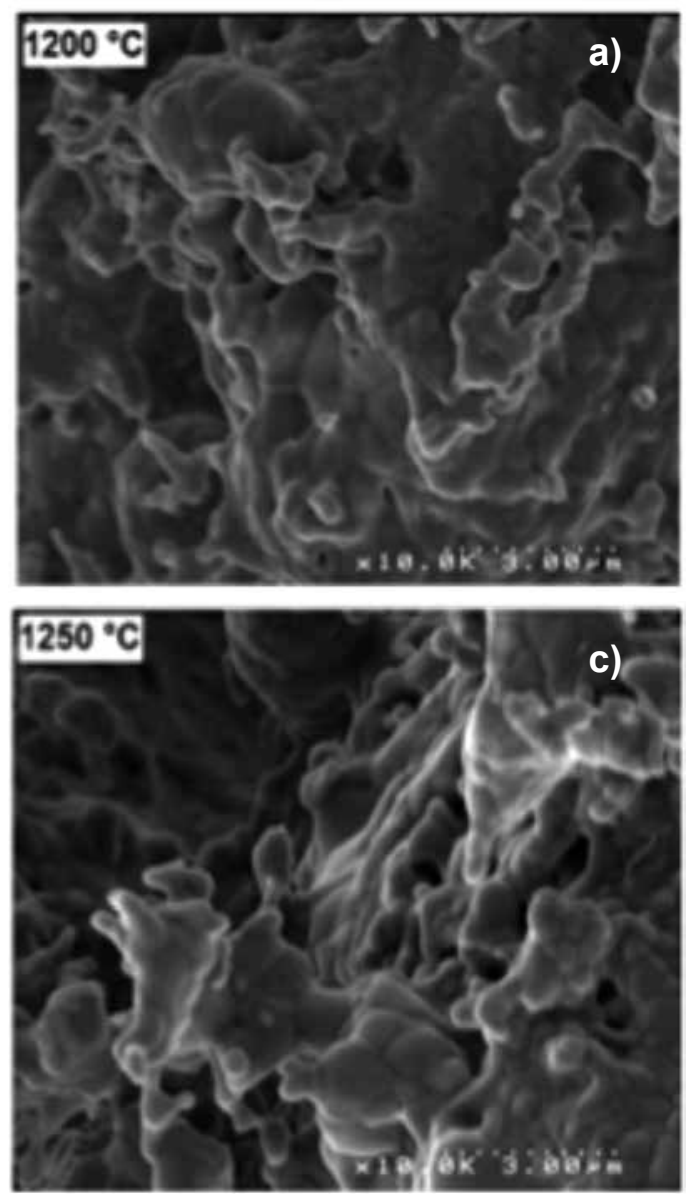

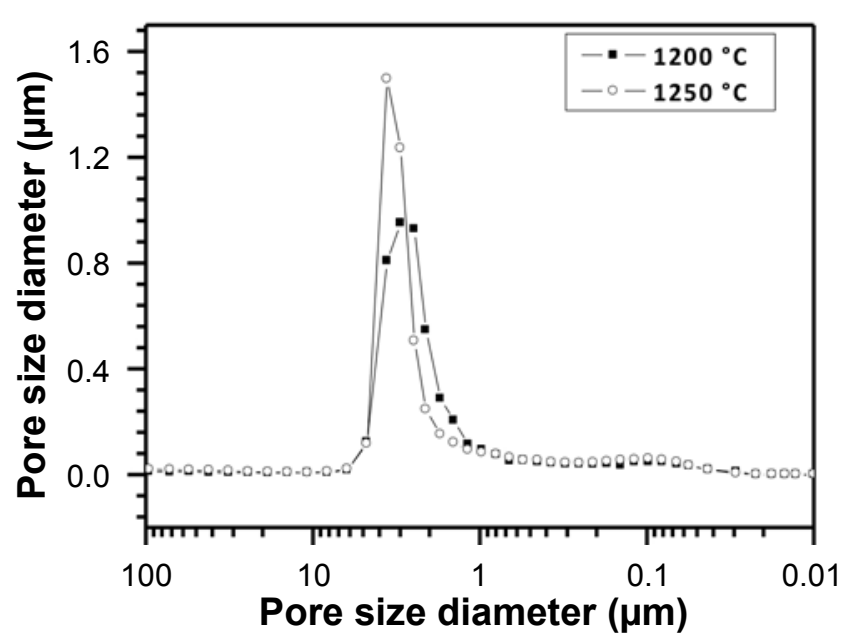

Figure 7: Pore size distribution in kaolin $+28 \mathrm{wt} \%$ calcite samples sintered at 1200 and $1250{ }^{\circ} \mathrm{C}$ for $1 \mathrm{~h}$.

[Figura 7: Distribuição de tamanho de poro na mistura caulim + $28 \%$ de calcita sinterizada a 1200 e $1250{ }^{\circ} \mathrm{C}$ por $\left.1 \mathrm{~h}.\right]$
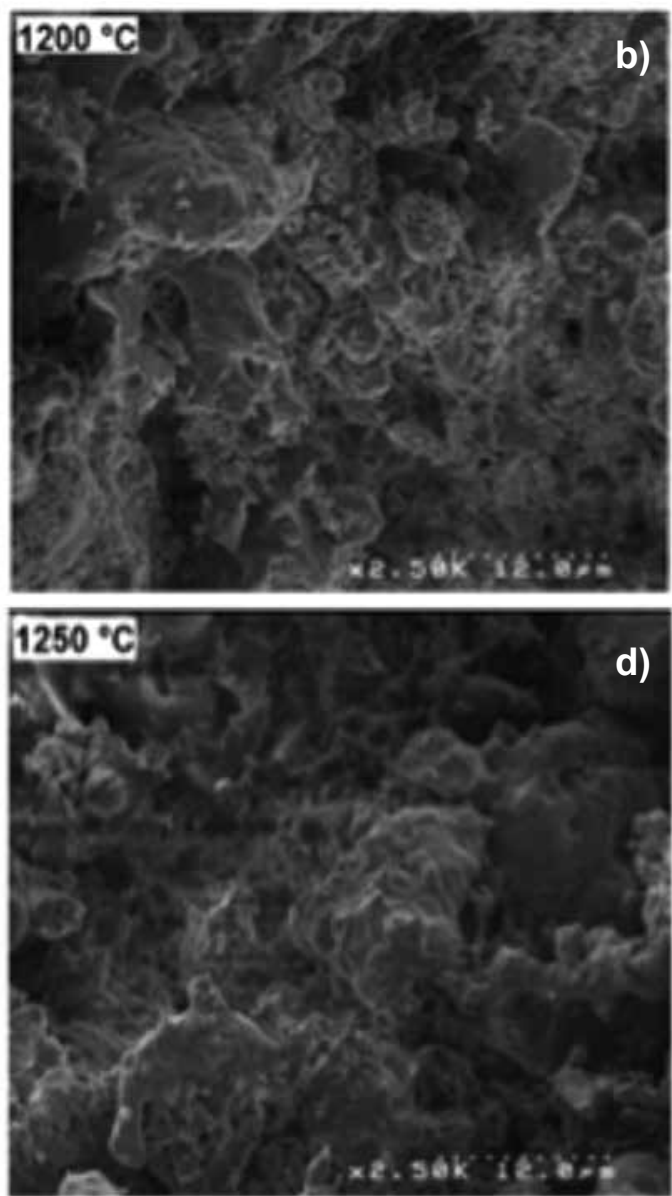

Figure 8: SEM micrographs of support cross-section (kaolin $+28 \mathrm{wt} \%$ calcite) samples sintered at 1200 and $1250{ }^{\circ} \mathrm{C}$.

[Figura 8: Micrografias obtidas por microscopia eletrônica de varredura da seção transversal de suporte (caulim $+28 \%$ calcita) de amostras sinterizadas a 1200 e $1250{ }^{\circ} \mathrm{C}$.]

These kinds of pore size distribution curves do not tell us more information about both cumulative porous volume and average pore size (APS). Consequently, curves of cumulative porous volume versus pore diameter were re- plotted in Fig. 9. It should be mentioned that the APS is directly given by mercury intrusion porosimetry. Moreover, these values are in good agreement with those determined also from the pore size corresponding to $50 \%$ of cumulative 


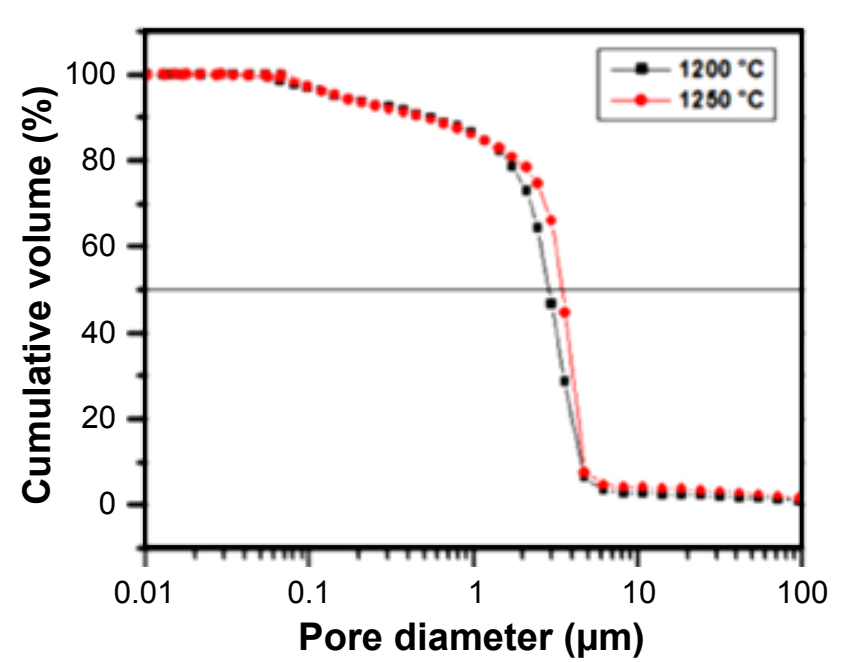

Figure 9: Cumulative porous volume as a function of pore size for kaolin $+28 \mathrm{wt} \%$ calcite samples sintered at 1200 and $1250{ }^{\circ} \mathrm{C}$ for $1 \mathrm{~h}$.

[Figura 9: Volume de poro acumulativo em função do tamanho do poro para amostras de caulim $+28 \%$ de calcita sinterizadas a 1200 e $1250{ }^{\circ} \mathrm{C}$ por $\left.1 \mathrm{~h}.\right]$

volume (Fig. 9). This graph shows mainly that the APS is shifted towards higher values when sintering temperature is increased. These values correspond to a cumulative porous volume of $50 \%$ (Fig. 9). Furthermore, these curves may inform us about the percentage of any pore size interval, at a given sintering temperature.

\section{Phase identification}

$\mathrm{X}$-ray diffraction was used to identify the formed phases. In kaolin $+28 \mathrm{wt} \%$ calcite materials, heated at $1250{ }^{\circ} \mathrm{C}$, the main observed phases are: anorthite $\left(\mathrm{CaO} \cdot \mathrm{Al}_{2} \mathrm{O}_{3} \cdot 2 \mathrm{SiO}_{2}\right)$ and gehlenite $\left(2 \mathrm{CaO} \cdot \mathrm{Al}_{2} \mathrm{O}_{3} \cdot \mathrm{SiO}_{2}\right)$. These identified phases (Fig. 10) are of great importance because of their promising

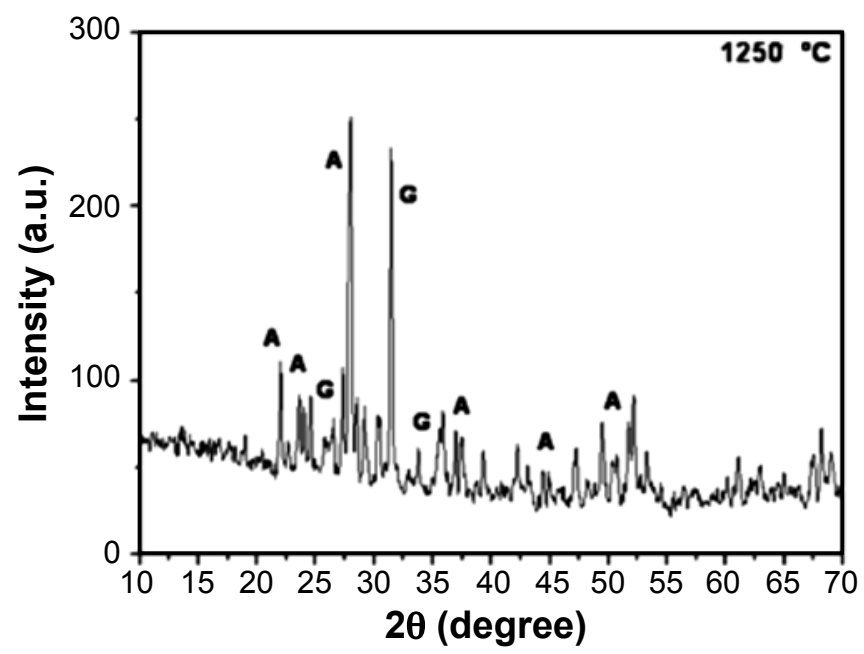

Figure 10: X-ray diffraction pattern of kaolin $+28 \mathrm{wt} \%$ calcite sample sintered at $1250{ }^{\circ} \mathrm{C}$ for $1 \mathrm{~h}$ : G, gehlenite; A, anorthite.

[Figura 10: Difratograma de raios X da amostra caulim $+28 \%$ de calcita sinterizada a $1250{ }^{\circ} \mathrm{C}$ por $1 \mathrm{~h}$ : G, guelenita; A, anortita.] physical and mechanical properties. For example, anorthite is a useful refractory for high-temperature ceramics applications, because of its low thermal expansion and high creep resistance. In addition to this, it has a high load bearing capacity, abrasion and corrosion resistance. The formed phases mentioned above are chemically stable in acids. The objective of this section is to prepare porous gehleniteanorthite based ceramics but relatively well sintered. Really, Fig. 8 confirms the relatively good sinterability of samples at 1200 and $1250^{\circ} \mathrm{C}$.

\section{CONCLUSIONS}

Macro-porous gehlenite-anorthite based ceramics supports for membranes have been effectively fabricated using inexpensive clay mixtures (kaolin and calcite) by the compaction technique. The prepared supports offered high porosity $(54 \%)$, good average pore size $(6 \mu \mathrm{m})$ and a uniform pore size distribution (mono-modal). It possibly can be used under severe conditions such as higher temperatures. Furthermore, these porous ceramics may have a potential use in a wide range of applications due to the excellent combination of their properties.

\section{REFERENCES}

[1] A. Harabi, S. Achour, J. Mater. Sci. Lett. 18 (1999) 955. [2] A. Mecif, J. Soro, J.P. Bonnet, A. Harabi, J. Am. Ceram. Soc. 93 (2010) 1306.

[3] A. Harabi, N. Karboua, S. Achour, Int. J. Appl. Ceram. Technol. 9 (2012) 124.

[4] A. Harabi, F. Bouzerara, S. Condom, Des. Wat. Treat. 6 (2009) 222.

[5] B. Boudaira, A. Harabi, F. Bouzerara, S. Condom, Des. Wat. Treat. 9 (2009) 142.

[6] F. Bouzerara, A. Harabi, S. Condom, Des. Wat. Treat. 12 (2009) 415.

[7] A. Harabi, A. Guechi, S. Condom, Procedia Eng. 33 (2012) 220.

[8] F. Bouzerara, A. Harabi, B. Ghouil, N. Medjemem, B. Boudaira, S. Condom, Procedia Eng. 33 (2012) 78.

[9] A. Harabi, F. Zenikheri, B. Boudaira, F. Bouzerara, A. Guechi, L. Foughali, J. Eur. Ceram. Soc. 34 (2014) 1329.

[10] L. Foughali, A. Harabi, S.E. Barama, F. Bouzerara, A. Guechi, B. Boudaira, Des. Wat. Treat. 57 (2016) 5303.

[11] F. Bouzerara, S. Boulanacer, A. Harabi, Ceram. Inter. 41 (2015) 5159.

[12] A. Harabi, B. Boudaira, F. Bouzerara, L. Foughali, F. Zenikheri, A. Guechi, B. Ghouil, S. Condom, Acta. Phys. Pol. A 127 (2015) 1164.

[13] B. Boudaira, A. Harabi, F. Bouzerara, F. Zenikheri, A. Guechi, Des. Wat. Treat. 57 (2016) 5258.

[14] A. Guechi, A. Harabi, S. Condom, F. Zenikheri, B. Boudaira, F. Bouzerara, L. Foughali, Des. Wat. Treat. 57 (2016) 5246.

[15] B. Ghouil, A. Harabi, F. Bouzerara, Des. Wat. Treat. 57 (2016) 5241. 
[16] B. Ghouil, A. Harabi, F. Bouzerara, B. Boudaira, A. Guechi, M.M. Demir, A. Figoli, Mater. Charact. 103 (2015) 18.

[17] N. Mdjemem, A. Harabi, F. Bouzerara, L. Foughali, B. Boudaira, A. Guechi, N. Brihi, J. Taiwan Inst. Chem. Eng. 59 (2016) 79.

[18] A. Guechi, S. Achour, A. Harabi, Key Eng. Mater. 264268 (2012) 57.

[19] F. Bouzerara, S. Boulanacer, A. Harabi, B. Boudaira, S. Achour, S. Condom, Phys. Procedia 2 (2009) 449.

[20] A. Harabi, D. Belamri, N. Karboua, F.Z. Mezahi, J. Therm. Anal. Calorim. 104 (2011) 283.

[21] A. Harabi, E. Harabi, S. Chehalatt, S. Zouai, N. Karboua, L. Foughali, Des. Wat. Treat. 57 (2016) 5303.

[22] E. Harabi, A. Harabi, F.Z. Mezahi, S. Zouai, N. Karboua, S. Chehalatt, Des. Wat. Treat. 57 (2016) 5297.

[23] E. Harabi, A. Harabi, L. Foughali, S. Chehlatt, S. Zouai, F.Z. Mezahi, Acta. Phys. Pol. A 127 (2015) 1161.

[24] F.Z. Mezahi, H. Oudadesse, A. Harabi, A. Lucas-Girot, Int. J. Appl. Ceram. Technol. 9 (2012) 529.

[25] A. Harabi, S. Chehlatt, J. Therm. Anal. Calorim. 111 (2013) 203.

[26] A. Harabi, S. Zouai, Int. J. Appl. Ceram. Technol. 11 (2014) 31.

[27] S. Chehlatt, A. Harabi, E. Harabi, S. Zouai, H.
Oudadesse, S.E. Barama, Des. Wat. Treat. 57 (2016) 5292. [28] S. Chehlatt, A. Harabi, H. Oudadesse, E. Harabi, Acta. Phys. Pol. A 127 (2015) 925.

[29] A. Harabi, E. Harabi, Mater. Sci. Eng. C 51 (2015) 206. [30] Y. Dong, B. Lin, J. Zhou, X. Zhang, Y. Ling, X. Liu, G. Meng, S. Hampshire, Mat. Charact. 62, 4 (2011) 409.

[31] N. Saffaj, S. Alami Younssi, A. Albizane, A. Messouadi, M. Bouhria, M. Persin, M. Cretin, A. Larbot, Sep. Purif. Technol. 36 (2004) 107.

[32] S. Masmoudi, A. Larbot, H. El Feki, R. Ben Amar, Desalination 190 (2006) 89.

[33] S. Masmoudi, R. Ben Amar, A. Larbot, H. El Feki, A. Ben Salah, L. Cot, J. Membr. Sci. 247 (2005) 1.

[34] T.V. Gestel, C. Vandecasteele, A. Buekenhoudt, C. Dotremont, J. Luyten, R. Leysen, J. Membr. Sci. 207 (2002) 73.

[35] G.E. Romanos, Th.A. Steriotis, E.S. Kikkinides, N.K. Kanellopoulos, V. Kasseelouri, I, J. Eur. Ceram. Soc. 21 (2001) 119.

[36] S.H. Zhong, C.F. Li, X.F. Xiao, J. Membr. Sci. 199 (2002) 53.

[37] N. Saffaj, S.A. Younssi, A. Albizane, A. Messouadi, M. Bouhria, M. Persin, Desalination 168 (2004) 259.

[38] T. Mohammadi, A. Pak, Purif. Technol. 30 (2003) 241. (Rec. 30/10/2015, Rev. 22/12/2015, 08/02/2016, Ac. $07 / 03 / 2016)$ 